\title{
Cloacibacterium normanense gen. nov., sp. nov., a novel bacterium in the family Flavobacteriaceae isolated from municipal wastewater
}

Correspondence

Ralph S. Tanner

rtanner@ou.edu

\author{
Toby D. Allen, ${ }^{1}$ Paul A. Lawson, ${ }^{1}$ Matthew D. Collins, ${ }^{2}$ Enevold Falsen ${ }^{3}$ \\ and Ralph S. Tanner ${ }^{1}$ \\ 1Department of Botany and Microbiology, University of Oklahoma, Norman, OK 73019, USA \\ ${ }^{2}$ School of Food Biosciences, University of Reading, Reading RG6 6AP, UK \\ ${ }^{3}$ Culture Collection, Department of Clinical Bacteriology, University of Göteborg, SE-413 46 \\ Göteborg, Sweden
}

Members of the family Flavobacteriaceae are ubiquitous in aquatic habitats, where they are generally thought to play a role in the breakdown of complex organic matter (Bernardet et al., 2002). Members of this group are common in activated sludge and other parts of wastewater-treatment plants (Benedict \& Carlson, 1971; Güde, 1980). By using probes specific for the Cytophaga-Flavobacterium group, researchers have found that this group constitutes a significant portion (11-24\%) of the microbial community of activated sludge from wastewater plants that employ enhanced biological phosphate removal (Wagner et al., 1994; Liu et al., 2005), and that its members contribute directly to phosphate removal in activated sludge (Van Ommen Kloeke \& Geesey, 1999). Three isolates of a numerically dominant, heterotrophic, Gram-negative bacterium were recovered during a study of the impact of the discharge of treated wastewater into the Canadian River at Norman, OK, USA. Biochemical and phenotypic analysis showed that the organisms

Abbreviation: MPN, most probable number.

The GenBank/EMBL/DDBJ accession number for the 16S rRNA gene sequence of strain CCUG $46293^{\top}$ is AJ575430. possessed traits similar to those of species belonging to the Cytophaga-Flavobacterium-Bacteroides group of organisms (Paster et al., 1985; Segers et al., 1993). Studies involving 16S rRNA gene sequence analysis indicated that the isolates represented a new subline within the BergeyellaChryseobacterium-Riemerella branch of the Flavobacteriaceae (Vandamme et al., 1994; Bernardet et al., 1996). A most probable number (MPN)-PCR approach was developed to detect (and enumerate) this organism from the wastewater influent and from human stool samples, a possible source of the bacterium. It is therefore proposed that a novel genus and species be created to accommodate the novel organism recovered from sewage.

Isolates $\mathrm{NRS1}^{\mathrm{T}}, \mathrm{NRS30}$ and NRS32 were isolated from untreated wastewater from a water-treatment plant located at Norman, OK, USA. Strain NRS1 ${ }^{\mathrm{T}}$ was isolated as a most numerous culturable heterotroph from an MPN dilution series in $0.5 \times$ tryptic soy broth (Becton Dickinson). Strains NRS30 and NRS32 were isolated by direct plating of untreated wastewater from the same source on nutrient agar. Tryptic soy broth or tryptic soy agar (Becton Dickinson) was used for routine culture unless otherwise 
stated. The strains were characterized biochemically by using a combination of conventional tests performed as described previously (Smibert \& Krieg, 1991), and by using the API Rapid ID 32S, API Rapid ID 32A and API ZYM test systems according to the manufacturer's instructions (bioMérieux). Hydrolysis of casein, DNA and urea and reduction of nitrate were assessed by inoculation on the appropriate media (Becton Dickinson). Citrate utilization was assessed by using Simmons' citrate agar (Becton Dickinson). Hydrolysis of xanthine, hypoxanthine and uric acid was investigated by using the method of Bowman et al. (1996). Hydrolysis of alginate and chitin was investigated by using the method of West \& Colwell (1984) and pectin hydrolysis was assessed by using the method of Hildebrand (1971). Resistance to antibiotics was investigated by using the method of Bauer et al. (1966). The fermentation products of glucose were determined by using ion-exclusion HPLC with an Aminex HPX-87H column (Bio-Rad) and a mobile phase consisting of $0.0025 \mathrm{M} \mathrm{H}_{2} \mathrm{SO}_{4}$. The $\mathrm{pH}$ range and optimum was determined by incubation on $1.5 \%$ tryptone broth supplemented with one of the following (at $30 \mathrm{~g} \mathrm{l}^{-1}$ ): HOMOPIPES [homopiperazine- $N, N^{\prime}$-bis-2-(ethanesulfonic acid)] at $\mathrm{pH} 4$ and 5, MES [2-( $\mathrm{N}$-morpholino)ethanesulfonic acid] at $\mathrm{pH} 6$, TES [ $N$-tris(hydroxymethyl)methyl2 -aminoethanesulfonic acid] at $\mathrm{pH} 7$ and 8 or CAPSO [3-(cyclohexylamino)-2-hydroxy-1-propanesulfonic acid] at $\mathrm{pH} 9$.

Fatty acid methyl ester analysis was performed on overnight cultures grown on tryptic soy agar at $37^{\circ} \mathrm{C}$ by Microcheck, Inc. (Northfield, VT, USA) according to methods described previously (Miller, 1982; Sassar, 1990). For the detection of flexirubin-type pigments, pigmented cells were subjected to the $\mathrm{KOH}$ test as previously described for preliminary analysis (Hirsch \& Reichenbach, 1981). For further characterization of pigments, cells were grown on tryptic soy agar and the pigments were extracted with acetone. The cell debris was then pelleted and the crude extract was analysed by using a DU 640 spectrophotometer (Beckman Coulter). Isoprenoid quinones were extracted as described by Collins et al. (1977) and analysed by HPLC as described by Groth et al. (1997). DNA was isolated by the method of Lawson et al. (1989). The DNA G + C content (mol\%) was determined by HPLC according to Mesbah et al. (1989). The 16S rRNA genes of the isolates were amplified by PCRs using universal primers pA (positions 8-28, Escherichia coli numbering) and $\mathrm{pH}$ (positions 1542-1522) (Hutson et al., 1993). The amplified products were purified by using a QIAquick PCR purification kit (Qiagen) and directly sequenced with primers directed towards conserved positions of the rRNA gene and the dRhodamine terminator cycle sequencing kit (ABI) using an automatic DNA sequencer. The closest known relatives of the novel isolates were determined by performing database searches using the program FASTA (Pearson \& Lipman, 1985). These sequences and those of other related strains were retrieved from GenBank and aligned with the newly determined sequences by using the program SEQtools (Rasmussen, 2002). The resulting multiple sequence alignment was corrected manually using the program GeneDoc (Nicholas et al., 1997) and a phylogenetic tree was constructed according to the neighbourjoining method (Saitou \& Nei, 1987) with the programs SEQtools and TREEVIEW (Page, 1996). The stability of the groupings was estimated by bootstrap analysis (1000 replications) using the same programs. For the MPN-PCR analysis, a pair of oligonucleotide primers, Cloac-001f ( $5^{\prime}$-TATTGTTTCTTCGGAAATGA) and Cloac-001r (5'-ATGGCAGTTCTATCGTTAAGC), were designed (using Primer3 software; Rozen \& Skaletsky, 2000) that were specific to the 16S rRNA gene of the newly isolated organism. DNA was isolated from 10 human stool samples (200 $\mathrm{mg}$ each) by using the QIAamp DNA Stool Mini kit (Qiagen) according to the manufacturer's instructions. Cells were harvested from wastewater influent and effluent samples by centrifugation and were then washed with a saline buffer. Washed whole cells were then added to the PCR mixture after a freeze-thaw cycle to achieve lysis. MPN-PCR (Picard et al., 1992) was performed by means of serial 10 -fold dilutions in triplicate and visualization of the PCR product by agarose gel electrophoresis. The MPN was calculated according to the tables of Cochran (1950).

All strains stained Gram-negative and displayed pleomorphic cell morphologies depending on the medium used. In broth cultures, most cells were long (up to $27 \mu \mathrm{m}$ ); when cultured on agar plates, most cells were much shorter (5-9 $\mu \mathrm{m})$. Similar pleomorphic cell morphologies have been described for members of the Flavobacteriaceae (Simon \& White, 1971). A battery of phenotypic and biochemical tests, including API Rapid ID 32S, API Rapid ID 32A and API ZYM, were performed on all strains, the results of which appear in the genus and species descriptions and in Table 1. Sensitivities to the following antibiotics were tested: ampicillin $(10 \mu \mathrm{g})$, carbenicillin $(100 \mu \mathrm{g})$, cefaclor $(30 \mu \mathrm{g})$, ceftriaxone $(30 \mu \mathrm{g})$, chloramphenicol $(30 \mu \mathrm{g})$, ciprofloxacin $(5 \mu \mathrm{g})$, doxycycline $(30 \mu \mathrm{g})$, erythromycin $(15 \mu \mathrm{g})$, gentamicin $(10 \mu \mathrm{g})$, kanamycin $(30 \mu \mathrm{g})$, nalidixic acid $(30 \mu \mathrm{g})$, oxytetracycline $(30 \mu \mathrm{g})$, streptomycin $(10 \mu \mathrm{g})$, sulfathiazole $(0 \cdot 25 \mathrm{mg})$, tetracycline $(30 \mu \mathrm{g})$ and trimethoprim $(5 \mu \mathrm{g})$. All three strains were resistant to erythromycin and kanamycin; strain $\mathrm{NRS1}^{\mathrm{T}}$ was also resistant to streptomycin and strain NRS32 was resistant to nalidixic acid. The $\mathrm{KOH}$ test for flexirubin-type pigments was negative for all strains. The absorbance spectra of crude pigment extract from all strains exhibited a triple-peak signature $(418,451$ and $483 \mathrm{~nm})$ characteristic of carotenoid-type pigments (Schmidt et al., 1994). The fatty acid profiles of the newly isolated strains consisted mainly of branched-chain fatty acids, with iso$\mathrm{C}_{13: 0}(8-9 \%)$, iso- $\mathrm{C}_{15: 0}(40-46 \%)$, iso- $\mathrm{C}_{15: 1}(7-10 \%)$ and iso- $\mathrm{C}_{17: 0} 3-\mathrm{OH}(5-9 \%)$ predominating. The detailed fatty acid composition is shown in Table 2.

To ascertain the phylogenetic relationships of the unknown isolates, their 16S rRNA genes were sequenced and subjected to a comparative analysis. The almost complete gene sequences ( $>1500 \mathrm{nt}$ ) of the three strains were determined; 
Table 1. Differentiating characteristics for Cloacibacterium and other related genera

Symbols: + , positive for all strains studied; -, negative for all strains studied; V, varies within or between strains and species; ND, not determined for most strains. Data for Bergeyella and Chryseobacterium were obtained from Vandamme et al. (1994), Shimomura et al. (2005) and de Beer et al. (2005) and data for Riemerella were obtained from Segers et al. (1993) or from Vancanneyt et al. (1999).

\begin{tabular}{|c|c|c|c|c|}
\hline Characteristic & Cloacibacterium & Bergeyella & Riemerella & Chryseobacterium \\
\hline \multicolumn{5}{|l|}{ Production of: } \\
\hline DNase & + & - & ND & $+^{*}$ \\
\hline Urease & - & + & $\mathrm{v}$ & $\mathrm{V}$ \\
\hline Indole & + & + & $\mathrm{v}$ & $\mathrm{v}$ \\
\hline Aesculin hydrolysis & + & - & $\mathrm{v}$ & $+^{*}$ \\
\hline \multicolumn{5}{|l|}{ Growth at: } \\
\hline $37^{\circ} \mathrm{C}$ & + & + & + & $\mathrm{V}$ \\
\hline $42^{\circ} \mathrm{C}$ & - & $-\dagger$ & $+^{*}$ & $-\ddagger$ \\
\hline DNA G $+C$ content $(\mathrm{mol} \%)$ & 31 & $35-37$ & $33-37$ & $33-38$ \\
\hline
\end{tabular}

${ }^{*}$ Positive for most strains studied.

$\dagger$ Positive for one of the 30 B. zoohelcum strains studied.

$\ddagger$ Negative for most strains studied.

pairwise analysis showed that strain $\mathrm{NRS1}^{\mathrm{T}}$ exhibited $100 \%$ 16S gene sequence similarity to strain NRS30 and $99.6 \%$ similarity to strain NRS32. Sequence database searches confirmed that the unidentified, rod-shaped organism from human raw sewage did not correspond to any recognized Gram-negative bacterium and represented a previously

Table 2. Cellular fatty acid composition of Cloacibacterium strains

Values are percentages of total fatty acids. -, Not detected or present at less than $1 \%$.

\begin{tabular}{|c|c|c|c|}
\hline Fatty acid & $\mathrm{NRS1}^{\mathrm{T}}$ & NRS30 & NRS32 \\
\hline $\mathrm{C}_{12: 0} 3-\mathrm{OH}$ & $2 \cdot 1$ & $1 \cdot 0$ & $2 \cdot 1$ \\
\hline iso- $\mathrm{C}_{13: 0}$ & $7 \cdot 9$ & $9 \cdot 2$ & $9 \cdot 2$ \\
\hline anteiso- $\mathrm{C}_{13: 0}$ & $1 \cdot 1$ & - & $1 \cdot 0$ \\
\hline iso- $\mathrm{C}_{14: 0}$ & $3 \cdot 3$ & $2 \cdot 8$ & $3 \cdot 4$ \\
\hline $\mathrm{C}_{15: 0}$ & $1 \cdot 1$ & - & - \\
\hline iso- $\mathrm{C}_{15: 0}$ & $40 \cdot 8$ & $43 \cdot 0$ & $45 \cdot 8$ \\
\hline anteiso- $\mathrm{C}_{15: 0}$ & $5 \cdot 0$ & $5 \cdot 7$ & $6 \cdot 2$ \\
\hline iso- $\mathrm{C}_{15: 0} 3-\mathrm{OH}$ & $3 \cdot 5$ & $4 \cdot 4$ & $3 \cdot 9$ \\
\hline iso- $\mathrm{C}_{15: 1}$ & $7 \cdot 8$ & $7 \cdot 0$ & $10 \cdot 2$ \\
\hline anteiso- $C_{15: 1}$ & $5 \cdot 4$ & $4 \cdot 0$ & - \\
\hline $\mathrm{C}_{16: 0}$ & - & $1 \cdot 3$ & - \\
\hline iso- $\mathrm{C}_{16: 0}$ & $1 \cdot 7$ & - & $1 \cdot 0$ \\
\hline $\mathrm{C}_{16: 0} 3-\mathrm{OH}$ & $1 \cdot 0$ & - & - \\
\hline iso- $\mathrm{C}_{16: 0} 3-\mathrm{OH}$ & $2 \cdot 5$ & $1 \cdot 9$ & $1 \cdot 8$ \\
\hline $\mathrm{C}_{16: 1} \omega 5 c$ & $1 \cdot 0$ & - & - \\
\hline iso- $\mathrm{C}_{17: 0} 3-\mathrm{OH}$ & $5 \cdot 3$ & $8 \cdot 6$ & $4 \cdot 8$ \\
\hline
\end{tabular}

unknown taxon. The results of neighbour-joining analysis, shown in Fig. 1, confirmed that the unknown bacterium (as exemplified by strain $\mathrm{NRS}^{\mathrm{T}}$ ) is a member of the Bergeyella-Chryseobacterium-Riemerella cluster of the Flavobacteriaceae. In particular, the unknown bacterium forms an association with a cluster of organisms that includes Riemerella anatipestifer $(88 \cdot 8 \%$ sequence similarity), Riemerella columbina (94.6\% sequence similarity), Bergeyella zoohelcum (94.4\% sequence similarity) and an as-yet uncultured bacterium $(99 \cdot 2 \%$ sequence similarity) recovered from uranium mining waste (Fig. 1).

Because this organism is present in large numbers in untreated wastewater, it was postulated that the source of the organism may have been the human gastrointestinal tract. An MPN-PCR strategy was developed to investigate this possibility. Primers were designed that were specific to the 16S rRNA gene sequence of the newly isolated organism, yielding a 557 bp PCR fragment from DNA isolated from all three strains. Organisms phylogenetically close to the three isolates (Bergeyella and Riemerella species) were challenged with the primers and gave negative results (data not shown). A pure culture of strain $\mathrm{NRS1}^{\mathrm{T}}$ yielded

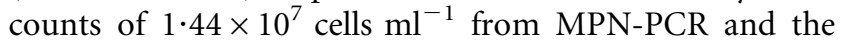
spread-plate method yielded a mean cell count of $4.03 \times$ $10^{7}$ cells $\mathrm{ml}^{-1}$, showing that comparable numbers of organisms can be recovered by these two methods. Untreated wastewater from the Norman plant yielded an estimated

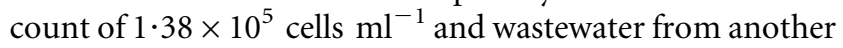
plant (Moore, OK, USA) yielded an estimated $1.38 \times$ $10^{4}$ cells $\mathrm{ml}^{-1}$. Signal was not detected from wastewater effluent. Signal was also not detected in any of the 10 human 


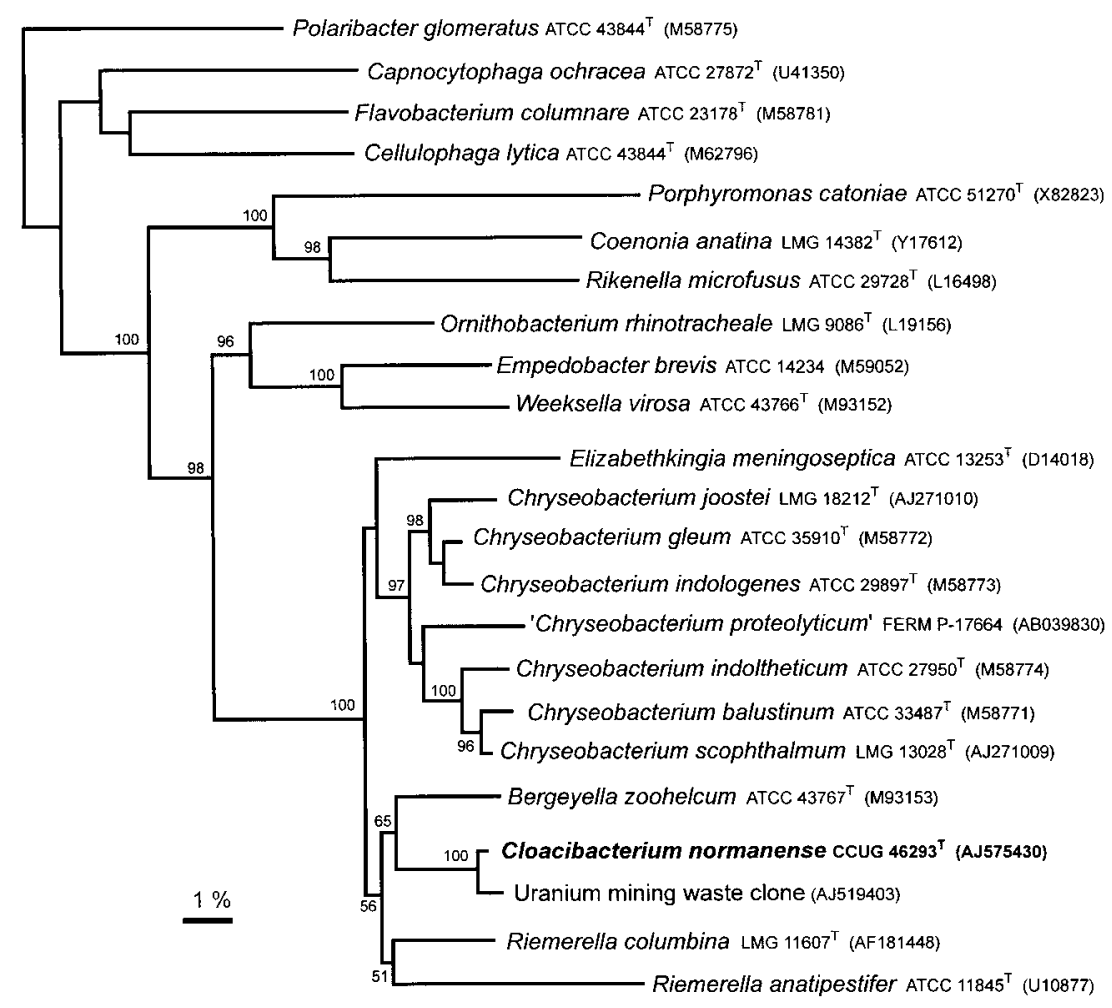

Fig. 1. Unrooted tree showing the phylogenetic relationships of Cloacibacterium normanense gen. nov., sp. nov. and some related Gram-negative bacteria. The tree, constructed using the neighbour-joining method, was based on a comparison of approximately $1327 \mathrm{nt}$. Bootstrap values, expressed as percentages of 500 replications, are given at branching points. Bar, $1 \%$ sequence divergence. stool samples, indicating that the newly isolated bacterium was not a dominant member of the human gastrointestinal tract (though it cannot be discounted as being present in smaller numbers, below the level of detection of the MPNPCR method used). More samples may need to be screened to confirm this result. However, this organism was found in large numbers in untreated wastewater, where it may play a role in the removal of phosphate. A phylogenetic relative of this organism (Chryseobacterium defluvii) was isolated from a phosphate-removing mixed culture obtained from activated sludge (Kämpfer et al., 2003).

On the basis of tree-topology considerations and sequencedivergence values of $5 \%$ or more with respect to the aforementioned taxa, the unidentified bacterium was only distantly related to these taxa and merits classification at a similar taxonomic rank (i.e. genus). Therefore, on the basis of both the phenotypic and the phylogenetic findings, we consider that the unknown Gram-negative rod isolated from raw sewage merits classification in a novel genus and a novel species, for which the name Cloacibacterium normanense gen. nov., sp. nov. is proposed. Characteristics that are useful in distinguishing Cloacibacterium normanense from its closest phylogenetic relatives are shown in Table 1.

\section{Description of Cloacibacterium gen. nov.}

Cloacibacterium (Clo.a'ci.bac.te' ri.um. L. fem. n. cloaca a sewer, canal; L. neut. n. bacterium a small rod; N.L. neut. n. Cloacibacterium a sewer rod).
Cells are Gram-negative, non-motile and pleomorphic rodshaped. Pigment is not of the flexirubin-type. Yellow to orange carotenoid-type pigments are produced. Facultatively anaerobic. Catalase- and oxidase-positive. The major end product of glucose fermentation under both aerobic and anaerobic conditions is pyruvate. Fatty acids consist mainly of branched-chain fatty acids, with iso- $\mathrm{C}_{13: 0}$, iso- $\mathrm{C}_{15: 0}$, iso$\mathrm{C}_{15: 1}$ and iso- $\mathrm{C}_{17: 0} 3-\mathrm{OH}$ predominating. The predominant respiratory quinone is MK-6. The DNA G $+\mathrm{C}$ content of the type strain of the type species is $31 \mathrm{~mol} \%$. The type species is Cloacibacterium normanense.

\section{Description of Cloacibacterium normanense sp. nov.}

Cloacibacterium normanense (nor.man.en'se. N.L. neut. adj. normanense pertaining to the city of Norman, OK, USA, where the organism was first isolated).

Displays the following features in addition to those given in the genus description. In broth cultures, cells are long (up to $27 \mu \mathrm{m})$; cells from agar plate cultures are much shorter (5-9 $\mu \mathrm{m})$. After $48 \mathrm{~h}$, colonies grown on tryptic soy agar are $1.0-1.5 \mathrm{~mm}$ in diameter, round, entire and very waxy. Growth occurs between 18 and $36^{\circ} \mathrm{C}$. No growth occurs at $4{ }^{\circ} \mathrm{C}$ or at $40{ }^{\circ} \mathrm{C}$ or above. No growth occurs on MacConkey agar. Optimum temperature for growth is $30^{\circ} \mathrm{C}$. All strains grow at pH 7 and 8; some strains also grow at pH 6 and 9. The $\mathrm{pH}$ optimum for all strains is 7. Indole-positive. Starch, aesculin, gelatin and casein are hydrolysed and DNA is hydrolysed weakly. Urea, chitin, pectin, alginate, uric acid, 
xanthine and hypoxanthine are not hydrolysed. Methyl red- and Voges-Proskauer-negative. Nitrate is not reduced. Cellulose and agar are not degraded. Most isolates tested are resistant to erythromycin $(15 \mu \mathrm{g})$ and kanamycin $(30 \mu \mathrm{g})$. All isolates tested are sensitive to carbenicillin $(100 \mu \mathrm{g})$, chloramphenicol $(30 \mu \mathrm{g})$, ciprofloxacin $(5 \mu \mathrm{g})$, doxycycline $(30 \mu \mathrm{g})$, gentamicin $(10 \mu \mathrm{g})$, oxytetracycline $(30 \mu \mathrm{g})$, sulfathiazole $(0 \cdot 25 \mathrm{mg})$ and tetracycline $(30 \mu \mathrm{g})$. With the API kits, acid is produced with $\alpha$-cyclodextrin and mannose. Acid is not produced from alanine, ribose, mannitol, sorbitol, lactose, trehalose, raffinose, hippurate, glycogen, melibiose, melezitose, sucrose, L-arabinose, D-arabitol, tagatose or raffinose. Enzyme activity is detected for alkaline phosphatase, acid phosphatase, alanine arylamidase, arginine dihydrolase (weak reaction), arginine arylamidase, chymotrypsin, esterase C-4 (weak reaction), ester lipase C8, $\alpha$-glucosidase, $\beta$-glucosidase, glycine arylamidase, glycyl tryptophan arylamidase, proline arylamidase, leucine arylamidase, leucyl glycine arylamidase, maltose, phenylalanine arylamidase, alanine phenylalanine proline arylamidase, leucine arylamidase, naphthol-AS-BI-phosphohydrolase, pyroglutamic acid arylamidase, tyrosine arylamidase, histidine arylamidase, glutamyl glutamic acid arylamidase, serine arylamidase and valine arylamidase. Enzyme activity is not detected for $N$-acetyl- $\beta$-glucosaminidase, $\alpha$-arabinosidase, $\alpha$-fucosidase, $\alpha$-galactosidase, $\beta$-galactosidase, $\beta$ glucuronidase, glutamic acid arylamidase, $\alpha$-mannosidase, $\beta$-mannosidase, methyl $\beta$-D-glucopyranoside, pyroglutamic acid arylamidase, lipase $\mathrm{C} 14$ or trypsin. Fatty acids iso- $\mathrm{C}_{13: 0}$ (8-9\%), iso- $\mathrm{C}_{15: 0}(40-46 \%)$, iso- $\mathrm{C}_{15: 1}(7-10 \%)$ and iso$\mathrm{C}_{17: 0} 3-\mathrm{OH}(5-9 \%)$ predominate. The DNA G + C content is $31 \mathrm{~mol} \%$.

The type strain, $\mathrm{NRS1}^{\mathrm{T}}\left(=\mathrm{CCUG} 46293^{\mathrm{T}}=\mathrm{CIP} 108613^{\mathrm{T}}=\right.$ ATCC BAA $-825^{\mathrm{T}}=$ DSM $15886^{\mathrm{T}}$ ), was isolated from untreated human wastewater. Additional strains of the species, strains NRS30 (=CCUG 48043) and NRS32 ( =CCUG 48044), were also isolated from wastewater.

\section{Acknowledgements}

We are grateful to Professor Dr Hans G. Trüper for help with the derivation of the genus name and species epithet.

\section{References}

Bauer, A. W., Kirby, W. M. M., Sherris, J. C. \& Truck, M. (1966). Antibiotic sensitivity testing by a standardized single disk method. Am J Clin Pathol 45, 493-496.

Benedict, R. G. \& Carlson, D. A. (1971). Aerobic heterotrophic bacteria in activated sludge. Water Res 5, 1023-1030.

Bernardet, J.-F., Segers, P., Vancanneyt, M., Berthe, F., Kersters, K. \& Vandamme, P. (1996). Cutting a Gordian knot: emended classification and description of the genus Flavobacterium, emended description of the family Flavobacteriaceae, and proposal of Flavobacterium hydatis nom. nov. (basonym, Cytophaga aquatilis Strohl and Tait 1978). Int J Syst Bacteriol 46, 128-148.

Bernardet, J.-F., Nakagawa, Y. \& Holmes, B. (2002). Proposed minimal standards for describing new taxa of the family
Flavobacteriaceae and emended description of the family. Int J Syst Evol Microbiol 52, 1049-1070.

Bowman, J. P., Cavanaugh, J., Austin, J. J. \& Sanderson, K. (1996). Novel Psychrobacter species from Antarctic ornithogenic soils. Int J Syst Bacteriol 46, 841-848.

Cochran, W. G. (1950). Estimation of bacterial densities by means of the "most probable number". Biometrics 6, 105-116.

Collins, M. D., Pirouz, T., Goodfellow, M. \& Minnikin, D. E. (1977). Distribution of menaquinones in actinomycetes and coryneform bacteria. J Gen Microbiol 100, 221-230.

de Beer, H., Hugo, C. J., Jooste, P. J., Willems, A., Vancanneyt, M., Coenye, T. \& Vandamme, P. A. R. (2005). Chryseobacterium vrystaatense sp. nov., isolated from raw chicken in a chicken-processing plant. Int J Syst Evol Microbiol 55, 2149-2153.

Groth, I., Schumann, P., Rainey, F. A., Martin, K., Schuetze, B. \& Augsten, K. (1997). Demetria terragena gen. nov., sp. nov., a new genus of actinomycetes isolated from compost soil. Int $J$ Syst Bacteriol 47, 1129-1133.

Güde, H. (1980). Occurrence of cytophagas in sewage plants. Appl Environ Microbiol 39, 756-763.

Hildebrand, D. C. (1971). Pectate and pectin gels for differentiation of Pseudomonas sp. and other bacterial pathogens. Phytopathology 61, 1430-1436.

Hirsch, I. \& Reichenbach, H. (1981). The Cytophaga-like bacteria: a search for key characters. In The Flavobacterium-Cytophaga Group, pp. 145-151. Edited by H. Reichenbach \& O. B. Weeks. Deerfield Beach, FL: Verlag Chemie.

Hutson, R. A., Thompson, D. E. \& Collins, M. D. (1993). Genetic interrelationships of saccharolytic Clostridium botulinum types B, E and $\mathrm{F}$ and related clostridia by small-subunit rRNA gene sequences. FEMS Microbiol Lett 108, 103-110.

Kämpfer, P., Dreyer, U., Neef, A., Dott, W. \& Busse, H.-J. (2003). Chryseobacterium defluvii sp. nov., isolated from wastewater. Int J Syst Evol Microbiol 53, 93-97.

Lawson, P. A., Gharbia, S. E. \& Clarke, D. R. (1989). Recognition of Fusobacterium nucleatum subgroups Fn-1, Fn-2 and Fn-3 by ribosomal RNA gene restriction patterns. FEMS Microbiol Lett 53, $41-45$.

Liu, Y., Zhang, T. \& Fang, H. H. P. (2005). Microbial community analysis and performance of a phosphate-removing activated sludge. Bioresour Technol 96, 1205-1214.

Mesbah, M., Premachandran, U. \& Whitman, W. B. (1989). Precise measurement of the $\mathrm{G}+\mathrm{C}$ content of deoxyribonucleic acid by highperformance liquid chromatography. Int J Syst Bacteriol 39, 159-167.

Miller, L. T. (1982). Single derivatization method for routine analysis of whole-cell fatty acid methyl esters. J Clin Microbiol 16, 584-586.

Nicholas, K. B., Nicholas, H. B., Jr \& Deerfield, D. W., II (1997). GeneDoc: analysis and visualization of genetic variation. EMBNEW News 4, 14.

Page, R. D. M. (1996). TREEVIEW: an application to display phylogenetic trees on personal computers. Comput Appl Biosci 12, 357-358.

Paster, B. J., Ludwig, W., Weisburg, W. G., Stackebrandt, E., Hespell, R. B., Hahn, C. M., Reichenbach, H., Stetter, K. O. \& Woese, C. R. (1985). A phylogenetic grouping of the bacteroides, cytophagas, and certain flavobacteria. Syst Appl Microbiol 6, 34-42.

Pearson, W. R. \& Lipman, D. J. (1985). Rapid and sensitive protein similarity searches. Science 227, 1435-1441.

Picard, C., Ponsonnet, C., Paget, E., Nesme, X. \& Simonet, P. (1992). Detection and enumeration of bacteria in soil by direct DNA extraction and polymerase chain reaction. Appl Environ Microbiol 58, 2717-2722. 
Rasmussen, S. W. (2002). SEQtools, a software package for analysis of nucleotide and protein sequences. Published on the internet at http://www.seqtools.dk

Rozen, S. \& Skaletsky, H. (2000). Primer3 on the WWW for general users and for biologist programmers. In Bioinformatics Methods and Protocols: Methods in Molecular Biology, pp. 365-386. Edited by S. Krawetz \& S. Misener. Totowa, NJ: Humana Press.

Saitou, N. \& Nei, M. (1987). The neighbor-joining method: a new method for reconstructing phylogenetic trees. Mol Biol Evol 4, 406-425.

Sassar, M. (1990). Identification of bacteria by gas chromatography of cellular fatty acids. MIDI Technical Note 101. Newark, DE: MIDI Inc.

Schmidt, K., Connor, A. \& Britton, G. (1994). Analysis of pigments: carotenoids and related polyenes. In Chemical Methods in Prokaryotic Systematics, pp. 403-461. Edited by M. Goodfellow \& A. G. O’Donnell. New York: Wiley.

Segers, P., Mannheim, W., Vancanneyt, M., De Brandt, K., Hinz, K.-H., Kersters, K. \& Vandamme, P. (1993). Riemerella anatipestifer gen. nov., comb. nov., the causative agent of septicemia anserum exsudativa, and its phylogenetic affiliation within the Flavobacterium-Cytophaga rRNA homology group. Int $J$ Syst Bacteriol 43, 768-776.

Shimomura, K., Kaji, S. \& Hiraishi, A. (2005). Chryseobacterium shigense sp. nov., a yellow-pigmented, aerobic bacterium isolated from a lactic acid beverage. Int J Syst Evol Microbiol 55, 1903-1906.
Simon, G. D. \& White, D. (1971). Growth and morphological characteristics of a species of Flexibacter. Arch Microbiol 78, 1-16.

Smibert, R. M. \& Krieg, N. R. (1991). Phenotypic characterization. In Methods for General and Molecular Microbiology, pp. 611-654. Edited by P. Gerhardt, R. G. E. Murray, W. A. Wood \& N. R. Krieg. Washington, DC: American Society for Microbiology.

Vancanneyt, M., Vandamme, P., Segers, P., Torck, U., Coopman, R., Kersters, K. \& Hinz, K.-H. (1999). Riemerella columbina sp. nov., a bacterium associated with respiratory disease in pigeons. Int J Syst Bacteriol 49, 289-295.

Vandamme, P., Bernardet, J.-F., Segers, P., Kersters, K. \& Holmes, B. (1994). New perspectives in the classification of the flavobacteria: description of Chryseobacterium gen. nov., Bergeyella gen. nov. and Empedobacter nom. rev. Int J Syst Bacteriol 44, 827-831.

Van Ommen Kloeke, F. \& Geesey, G. G. (1999). Localization and identification of populations of phosphatase-active bacterial cells associated with activated sludge. Microb Ecol 38, 201-214.

Wagner, M., Erhart, R., Manz, W., Amann, R., Lemmer, H., Wedi, D. \& Scheifer, K.-H. (1994). Development of an rRNA-targeted oligonucleotide probe specific for the genus Acinetobacter and its application for in situ monitoring in activated sludge. Appl Environ Microbiol 60, 792-800.

West, P. A. \& Colwell, R. R. (1984). Identification and classification of the Vibrionaceae - an overview. In Vibrios in the Environment, pp. 285-363. Edited by R. R. Colwell. New York: Wiley. 